\title{
Readability of Prose Forms: Pain or Gain?
}

\author{
${ }^{1}$ Revathi Gopal \\ \& \\ ${ }^{2}$ Che Ton Mahmud \\ Universiti Pendidikan Sultan Idris \\ Tanjung Malim, Perak, Malaysia \\ email: ${ }^{1}$ sivarev943@gmail.com, ${ }^{2}$ che.ton@fbk.upsi.edu.my.
}

\begin{abstract}
This paper aims to analyze the readability of the prose forms prescribed for students at the lower secondary level comprising short stories and a novel. The research question addressed is, "What are the text-reader factors which affect students' reading comprehension?' Interview sessions were carried out with 18 lower secondary students and the questions posed during the interview sessions focused on text-reader factors. Thematic analysis was carried out to analyze data from the verbatim transcription. The findings revealed that students were unhappy with certain physical aspects of the prose forms. Nonetheless, the literary texts used appears to match the readability level of the students involved. Results also show that the prose forms selected cater to all Malaysian lower secondary students of different language abilities and background. The weak students could be guided to read and understand the prose forms whereas the good students could improve themselves with enrichment activities.
\end{abstract}

Keywords: readability, prose forms, text-reader factors, text comprehension

\section{INTRODUCTION}

The literature component was integrated into the Malaysian secondary school English language syllabus with the advent hope that it would help to develop an interest in the English language. As such, students have been introduced to reading literary texts for aesthetic purposes. The use of these literary materials in English language classrooms for ESL learners is undeniably aimed at improving their proficiency in the language. As comprehension is key to improving proficiency and enhancing literacy at large, it is crucial that the current literary texts be analyzed for their readability. This is because any weaknesses in the literary texts selected will have implications in the teaching and learning environment.

*This article is based on a paper presented at the International Conference on the Teaching and Learning of Languages (ICTLL) 2017 organized by the Faculty of Languages and Communication, UPSI. 
In our move towards improving students' English language proficiency, the literary texts prescribed ideally should meet students' interest. Otherwise, a lapse would occur in between the text and the reader which cripples the reading process and text comprehension becomes a failure. Text-reader factors play a crucial role in determining students' readability level of literary texts. Readability is how well a reader can read and understand the text. According to Gilliland (1972) readability is the process of matching readers with the text and their interest. A similar view is shared by Dahlia Janan (2011) stating that the concept of readability is a matching process involving the dynamic interaction between both reader and text factors. The text-reader factors explored in the prose forms prescribed for the lower secondary school students include physical features of the text, genre, content, author, legibility, illustrations and organization whereas the reader factors analyzed were students' interest, prior knowledge and motivation.

\section{LITERATURE REVIEW}

The earliest definition of the term readability was given by Dale and Chall (1949). They stated that readability is, 'the sum total (including all the interactions) of all those elements within a given piece of printed material that affect the success a group of readers have with it' (as cited in DuBay, 2004, p. 3). The emphasis here is on the text and the reader. The reader's success in reading depends on the degree to which he or she understands the text and reading it at optimum speed. Two variables stressed in reader factors were readers' motivation and interest. For the text factor, the focus was on the quality of the written material.

Imran Ho and Ruzy Suliza Hashim (2007) share similar opinion as Dale and Chall (1949). They stated that readability involves both text and reader factors. Reader factor involves reader's motivation and cognitive ability whereas text factors include physical and linguistic aspects of the materials.

English and English (1958, as cited in Mealyea, 1979) focused specifically on text and its properties and claimed that an interesting reading material induces readers to read. Klare (1963, as cited in DuBay, 2004) defines readability as 'the ease of understanding or comprehension due to the style of writing' (p. 3). This definition focuses only on a text factor which is the writing style.

Likewise, Adlina Ismail, Normah Yusof and Kamariah Yunus (2016) posit that readability determines whether a text is easy or difficult to understand. The scholars view that readability is only concerned with the linguistic aspects of a text. Additionally, Marohaini Yusoff (1999) stated that readability is a concept which refers to the level or degree of difficulty-ease of reading a certain material. A material which is difficult to read is said to have a high readability level while a material which is easy to read is said to have a low readability level. A similar view is shared by Siti Rohani Kassim (2010), she stated that readability is a measurement of a level of ease or difficulty of reading materials and continues that the reader's abilities to read, understand and analyze any reading material means that the reader has mastered readability and legibility aspects. 
It appears that the definitions of readability among the scholars, local and abroad have the same focus. Their emphasis is either on text factors, text-reader factors or the level of difficulty of the text.

The notion of prose forms in this study refers to short stories and novels. Prose forms focus on plot and characters (Rosenblatt, 1976). The types of literature that fall into the prose category include essays, short stories, novels, and plays. An important aspect in every short story is a compact narrative and that characters are well-drawn (Lazar, 1993). According to Lazar (1993), the number of words for a short story is between 500 to 5,000 whereas a novel is longer in length.

The prose forms (short stories and novel) in the literature component that was analysed for their complexity in this study are 'Fair's Fair' by Narinder Dhami (Form One), 'Cheat' by Allan Baillie (Form Two) and the novel 'Railway Children' by Edith Nesbit (Form Three). All Malaysian lower secondary students are required to complete reading the prose forms prescribed before their final year examination.

\section{METHODOLOGY}

The study employed the qualitative research method in collecting and analyzing data. The qualitative data were obtained through in-depth interview sessions. The research question addressed in the study is "What are the text-reader factors which affect students' reading comprehension?" The participants were selected using the purposive sampling procedures. They comprise students from Form One to Form Three from a secondary school. Six participants were chosen in each form with a total of 18 students altogether. They were of medium ability and proficient in the English language.

\section{Research Instrument}

An interview protocol was developed based on text-reader factors. These include questions on (i) students' view on prose forms read, (ii) background knowledge, (iii) motivation in reading, (iv) elements that help students in reading, (v) preferred themes of prose texts, (vi) strengths, and (vii) weaknesses in reading.

\section{Data Analysis}

Data collected through the individual interview sessions were analyzed using the thematic analysis procedures where the data were constantly reviewed, synthesized, and compared to emerging themes (McMillan, 1996). Data reduction was carried out to select relevant data in tandem with the research question developed. The main themes and sub-themes were then categorized and coded. This process was followed by sorting verbatim units in relation to the themes and sub-themes identified.

A reliability check ensued. Two panel members were involved in the reliability check. The panel then compared the coded verbatim units selected with the transcribed verbatim to see whether they agree or disagree with the selection made by the researcher in the eighteen sets of verbatim transcript. Frequency counts of units were carried out to investigate the dominant data. 
The researcher used the Cohen Kappa Degree of Agreement Index to calculate the $\mathrm{K}$ value. The $\mathrm{K}$ value calculated was 0.98 which showed a high agreement above chance thus rendering the data reliable.

\section{RESULTS AND DISCUSSION}

The discussion on the analysis of readability of literary texts in lower secondary schools is based on students' views on the questions asked during the interview sessions.

\section{(i) Views On Prose Forms}

Research findings revealed that Form One participants find the short story, "Fairs Fair" by Narinder Dhami simple for their level.

"It is interesting, simple and easy to understand."(Form One).

The Form Two participants find the short story, "Cheat" by Allan Baillie, a normal story, relating to school happenings which did not create any excitement in them.

"Yes, it is normal story in students' life." (Form Two).

"I like the story it is about students in school." (Form Two).

"The story is ok but not very interesting." (Form Two).

It is enlightening to note that the Form Three participants find the novel, "The Railway Children" by Edith Nesbit, a nice and an interesting story which relates to family and teenagers' life experiences.

"It is interesting, a nice story to read, because it is adventurous and connects to teenagers lives." (Form Three).

Providing students with prose forms of students' choice contributes towards developing a positive attitude on reading (Leisure Reading Task Force, 2014). An interesting prose that relates to students' personal lives, would evoke their interest to read and be engaged in it. The student becomes enthusiastic to find out what happens as events unfold via the climax; he feels close to certain characters and shares their emotional responses. This can have beneficial effects during their participation in classroom activities. For example, students could share among themselves or the whole class their personal reactions about the characters in the story, theme(s), and the author's point of view. At this juncture, students' thinking skills are stimulated and their problem-solving abilities enhanced. As a result, students are able to perform well in their examinations.

\section{(ii) Background Knowledge}

Having similar experience as events depicted in the prose, the participants from Form 
One, Two and Three believed that they could remember the story better. Therefore, they could answer comprehension and essay questions in the classroom activities and examination literature questions confidently in their examination.

"cerita itu akan saya ingat .......saya boleh jawab soalan exam dengan baik. and affirmed, "Then I can score in my literature" (Form One).

"I can...can ingat kembali cerita tersebut sebab apa yang saya baca itu pernah saya alami". I can write well because saya tahu jalan cerita.

Boleh jawab dengan baik." (Form Two).

"I can remember the story well" and in exam, "I can answer the questions if I remember the story". (Form Three).

According to Lapp and Flood (1986), 'what we remember and infer from a passage depends on the knowledge that we bring to a passage'(p. 124). Background knowledge or prior knowledge helps students to make connections to the text they are reading to understand the text better. When students activate their background knowledge, they are actually linking what they already know to what they are currently reading. By activating prior knowledge, students are likely to assimilate old and new information. The ability to assimilate a particular information will have an impact on a students' ability to comprehend a text (Kucer, 2009). This helps in retaining information from a text.

In contrast, if students' fail in making sense of the prose, it is due to their lack of appropriate background knowledge that fit with the content of the prose (Brown, 2000). Hence, teachers in schools play an important role to activate and aid student's development of background knowledge. For example, teachers could begin the lesson by having brainstorming sessions with students on the topic, teaching words in categories, using contrasts and comparisons, analogies and using instructional aids such as pictures. This provides more opportunities for successful comprehension among students.

\section{(iii) Motivation}

Data revealed that students were motivated to read prose due to several reasons. Among others, reading widens their vocabulary, enable them to construct grammatically correct sentences, improve their English language, help them to gain knowledge on the topic and provide better opportunities to pursue tertiary education. Interestingly, they also believe that reading English language prose forms creates opportunities for students to improve their lives. Students know the importance of English Language, a widely used language in the modern world. Being well-versed in the language is a must for them to upgrade themselves to be better students and to ensure a bright future.

“Reading helps me to improve my English Language.” (Form One)

"I know more English words and ayat-ayat English I can write dengan betul." (Form Two) 
"If I'm good in English I can continue my studies in other countries." (Form Two).

"I know how to write good sentences in English Language." (Form Three).

Students' motivation to read help build confidence in them to be engaged with the text and to complete a reading task successfully. This would lead to a positive experience which in turn improves students' learning and achievement (Guthrie \& Wigfield, 1997).

\section{(iv) Elements That Help Students In Reading}

Text factors also affect readability. One of the text factors is the physical aspects of the text used. Six physical aspects were explored in the study. They are pictures, cover, text organization, font, glossary section and length. Also included is the author which is an element that helped students in reading and understanding the prose forms.

(a) Pictures

The participants from Form One, Two and Three preferred coloured pictures.

"colourful pictures are attractive and makes reading easier, "....ahhh... eemmm .... Sebab dia cerah and menarik perhatian. Kita boleh faham cerita" (Form One).

Some of the Form Three participants preferred black and white pictures. According to them, it brings back old memories.

"I like black and white, because it brings back old memories emm... like the olden days" (Form Three).

The use of pictures facilitates and promotes reading comprehension. As such, pictures should match the reading text to help readers understand both its content and language. Besides, it should not include too much information as this might confuse students. Moreover, colourful pictures along with the text capture students' attention and makes text comprehension easier. It connotes to Hibbing and Rankin-Erickson (2003) statement whereby they believe that pictures provide readers with a new source of information in addition to what they could get from reading the text itself. The two sources of information facilitate reading comprehension.

\section{(b) Cover}

In relation to the preference of the cover, Form One students liked it but not the Form Two students. They preferred a cover which is not too pink and bright.

"This book, the cover tak menarik perhatian sebab warnanya terlalu cerah. Semuanya pink colour" (Form One). 
The Form Three students like the cover of the book but they feel it needs to be improved.

"The cover is nice and beautiful but the colour black is not very attractive, should be replaced some bright colours. Black is gloomy." (Form Three).

The cover of a book is a deciding factor in choosing a book to read. The cover should communicate what is inside the book so that it convinces students to select and read the book. In this study, Form Two students were uncomfortable with the bright cover and the Form Three students did not favour a dark coloured cover. As such, both the cover did not contribute much in attracting students' attention. Therefore, in text selection, the design, colour and pictures laden on the cover are the physical aspects of texts which need to be addressed so as to create a positive mood and attitude for reading. Perhaps these aspects could be seriously taken into account by the publishers to ensure a good market.

\section{(c) Text organization}

According to all the Form One, Two and Three participants, they were satisfied with the organization of text in a narrative form.

"No problem, teacher. Can read. Dia tulis cara cerita, so tak ada masalah" (Form One).

"It is written well and there is a picture at every page that explains the story" (Form Three).

A text written in a narrative form keeps students focused in reading. They find it easy in comprehending a text. As students read, they could follow the storyline by reading through the pages. As they read students tend to imagine the characters, the events and they become absorbed in the story. At a certain point of the story, students can judge and give their opinion on how effectively it is written. This enhances students' creative and analytical thinking skills.

(d) Font

Form One students felt that the font in their literary text is quite big and font 14 would be suitable but the Form Two and Three students felt that the font used in the text is relevant to their level.

"The words are big like the primary school.” (Form One)

"The font is alright for me." (Form Two)

"The font is o.k." (Form Three)

The font used in writing the prose forms should be appropriate according to students' age. The Form One participants were uncomfortable with huge fonts. They 
felt that the huge fonts are suited more for the primary level as opposed to the secondary level in which they are in.

\section{(e) Glossary}

Data showed that all the participants preferred to have the glossary below each page instead of at the back of the book. They felt it would be easier for them to refer to the meaning of difficult words as they read through the pages.

"I prefer it to be below each page. It will be easy for me to refer." (Form One)

"I feel the words itu must put down here so that easy for me to know the meaning of words." (Form Two)

The glossary plays an important role in helping students understand difficult words. It is common for publishers to place the glossary at the back of books. However, students feel that it is not strategic. Turning the pages each time to search for the meaning of words is inconvenient. This prevents ease of reading among students and also disrupts their flow of thoughts. As such, based on the students' feedback, the glossary should best be placed below each page for fluent reading.

Length

Form One and Form Two participants believed that the length of the prose selected is relevant to their level whereas Form Three students felt that their novel is lengthy.

"The length is alright for me. It is not too long." (Form One).

"I feel it is a bit long. it is a bit long and I feel it is quite draggy, the end part of it." (Form Three)

Form Three participants were unhappy with the length of the novel. The novel contains nine chapters. The participants were of the opinion that the story could be shortened to seven chapters. It is because they could guess the ending part of the story. Moreover, these participants (who will have to sit for their PT3 examination) insist that they need to pay equal attention to other subjects as well such as Science, Malay literature and Mathematics. A lengthy prose burdens students as they have to commit much of their time and effort in understanding the text.

\section{(g) Author}

Most of the participants preferred foreign texts because they are used to reading them as compared to local texts which they are less exposed to.

"I like foreign because I read buku-buku mereka." (Form One).

"I like foreign authors. Idea mereka different dari local writers. I want to know more about many countries in the world." (Form Two). 
"I like foreign writers because I'm used to their books and I don't have any experience reading local writer's book." (Form Three).

Some participants preferred both local and foreign authors. They claimed that they are open to different ideas and perspectives on issues discussed by the authors.

"I like both, local and foreign writers." (Form One).

"Foreign writers, through their books I know more about their country, how they live, how they settle a problem in the family or masyarakat. Local writers pula I will know better about a society, our teenagers problems and they solved." (Form Three).

Apart from the physical aspects that helped and motivate students to read the prose forms, the writers of the prose play their role too. The prose forms prescribed for the lower secondary students are written by foreign writers. Students prefer foreign writers because they favour their writing style and the issues discussed. However, prose forms written by local writers should be exposed to students to open their mind to internal issues. Reading prose forms written by both foreign and local writers paves the way for students to compare and contrast their ideas from different perspectives. It enhances students' thinking skills.

\section{(v) Preferred Themes}

The common prose themes preferred by all the participants were war, horror, mystery, adventure, family stories, teenage life and comedy. Obviously, the preference of prose themes links to gender. Female participants preferred family stories, teenage life and the male participants preferred war, horror and adventure. If students are catered with the prose forms of their preferences, positive attitude towards reading would be developed.

"I like horror, family stories, mystery, life tentang teenager." (Form One, female).

"I like horror, war, adventure and comedy." (Form Two, male).

\section{(vi) Weaknesses In Reading}

The salient weakness in reading is the ability to understand difficult words and sentences. Hence, to overcome the difficulty, participants made close reference to the dictionary, surf the internet, read many times as in re-reading, consult their siblings and also their teacher.

"Sometimes when I read I don't understand the words and the sentences." (Form One participant). 
"I don't understand difficult words Maksud perkataan saya akan cari kat dictionary and internet." (Form One).

“Saya akan baca sehingga faham." (Form Two).

"I do not know words, I ask my friends and teacher." (Form Two).

"The meaning of words difficult to understand teacher and difficult long sentences, I don't understand." (Form Three).

\section{(vii) Strengths In Reading}

Reading prose texts has also rendered positive results in terms of developing students' strengths in reading. Results show that through reading the prose forms students are able to widen their vocabulary.

"Saya akan tahu English words, menambahkan kosa kata, know the sentences." (Form One)

"Reading English books I know many new words and ayat-ayat BI, saya boleh faham. (Form Two)

"I know many words, teacher" (Form Three)

Moreover, students are able to improve their reading skills. When they are able to read and understand the prose they feel that they could answer comprehension questions.

"I know many words and English sentences. I can answer soalan pemahaman dengan baik." (Form One)

"After I read, I faham and then can the questions." (Form Two)

"The more I read I know more sentences in English. I can understand the language and can answer the questions." (Form Three)

Apart from that, students also improve their speaking and writing skills.

"emmm..... English is important if I read more I can speak good English like the Western people.” (Form One)

"Em .... Ahh.... My English get better. Saya boleh baca dengan baik dan ini akan meningkatkan pengetahuan saya dalam Bahasa Inggeris." (From Two).

"I can speak well." (Form Three)

"I know more English words. Ini menolong saya apabila saya nak buat ayatayat English dengan betul dalam kerja sekolah terutama.. dalam... Emmm... 
dalam karangan BI saya. I know ....emm... to make ayat complex and simple sentences." (Form One)

"Emmmm... ahhh..... teacher, I think saya boleh write English well dalam karangan BI saya." (From Two)

"I can use the words when I write my composition to get good grades. I know many words and by reading I know the sentence structures, this helps me in my exam I can write English well and speak well. I can be somebody in the future." (Form Three).

It can be seen that the students gain lots of benefits to upgrading their English language proficiency level provided that they could read and understand the prose forms prescribed for them. In sum, the findings from the interview sessions have highlighted much information on the text and reader factors, which affect the readability of prose forms prescribed for the lower secondary students. The findings revealed that participants were both comfortable and partly uncomfortable with some aspects of the text factors as such as the cover, length of the novel and the font of words in the texts. When text factors affect participants' readability, it influences participants' interest and their motivation. As the text-reader factors are inter-related, an imbalance of these factors would hinder readability of prose texts. Nonetheless, participants in the lower secondary find the prose forms prescribed readable at their level.

\section{CONCLUSION}

The prose forms prescribed for the lower secondary school students are more of a gain than pain for students. It is apparent that students find that their language skills such as speaking, reading and writing are much improved. The enhancement of English language skills in a student would lead him or her to a bright future. Meanwhile, the defects and weaknesses found in certain physical aspects of the prose forms should be taken into consideration by the concerned authorities in selecting suitable prose forms that cater to the needs and taste of Malaysian students. When selecting literary texts to be used in language classrooms, the students' language proficiency, interests, age, sex and cultural background should be taken into account so as not to bore students with inappropriate materials. It is through reading an interesting prose text that students broaden their horizons and become familiar with other cultures. They learn to view the world from different perspectives. Besides, students can develop competence in the English language whereby they can express their ideas creatively and critically as well as become analytic learners. 


\section{REFERENCES}

Adlina Ismail, Normah Yusof, \& Kamariah Yunus. (2016). The readability of Malaysian English children books: A multilevel analysis. International Journal of Applied Linguistics \& English Literature, 5(6), 214.

Baillie, A. (2015). The cheat. Short story arena Form 2. Literature component for secondary schools. Kementerian Pendidikan Malaysia: Zulfashah Book Service.

Brown, H. D. (2000). Principles of language learning and teaching. New York: Pearson. Retrieved from http://www.glencoe.com/glencoe_research/Jamestown/motivation_and_engagement.pdf

Dahlia Janan. (2011). Towards a new model of readability. (Unpublished doctoral dissertation): University of Warwick, Tucson. Retrieved from http://wrap.warwick.ac.uk/51759/1/WRAP_THESIS_Janan_2011.pdf

DuBay, W. H. (2004). Principles of readability. Costa Mesa, CA: Impact Information. Retrieved from http://www.nald.ca/fulltext/readab/readab.pdf

Gilliland, J. (1972). Readability. London: University of London Press.

Guthrie, J. T., \& Wigfield, A. (1997). Relations of children's motivation for reading to the amount and breadth of their reading. Journal of Educational Psychology, 89(3), 420-432.

Hibbing, A. N. \& Rankin-Erickson, J. L. (2003). A picture is worth a thousand words: Using visual images to improve comprehension for middle school struggling readers.The Reading Teacher, 56(8), 758-770.

Imran Ho Abdullah,\& Ruzy Suliza Hashim. (2007). Readability analysis of Malaysian short stories in English. e-BANGI: Jurnal Sains Sosial dan Kemanusiaan, 2(2), 1-11.

Kucer, S. B. (2009). Dimensions of literacy: A conceptual base for teaching reading and writing in school settings (3rd ed.). Mahwah, NJ: Erlbaum.

Lapp, D., \& Flood, J. (1986). Teaching students to read. New York: MacMillan.

Leisure Reading Task Force. (2014). Position Statements. National Council of Teachers of English. Retrieved from http://www2.ncte.org/statement/leisure-reading/

Lazar, G. (1993). Literature and language teaching: A guide for teachers and trainers. Cambridge: Cambridge University Press.

MacMillan, J. H. (1996). Educational research: Fundamentals for the consumer (2 $2^{\text {nd }}$ ed.). Harper Collins: College Publishers. Retrieved from http://ww2.odu.edu/ jritz/attachments/edrefu.pdf

Marohaini Yusoff. (1999). Teaching reading and comprehension strategies. Kuala Lumpur: Institute of Language and Literature.

Mealyea, R. (1979). Readability: Concept and measurement. Retrieved from http://www.voced.edu.au/content/ngv\%3A29267

Narinder Dhami. (2014). Fair's fair. Literature component for secondary schools Form 1 (Student's edition.). Kementerian Pendidikan Malaysia: Zulfashah Book Service.

Nesbit, E. (2011). The railway children. Literature component for secondary schools. Form 3 (Student's edition.). Kuala Lumpur: Zirwah.

Rosenblatt, L. (1976). Literature as exploration. New York: Modern Language Association.

Siti Rohani Kassim. (2010). Literacy through children's literature: A Malaysian perspective. Malaysian Journal of Media Studies 12(2), 1-9. 